\title{
Whole-body propionate and glucose metabolism of multiparous dairy cows receiving folic acid and vitamin $B_{12}$ supplements
}

\author{
M. Duplessis, ${ }^{*}{ }^{1}$ H. Lapierre, ${ }^{*}$ B. Ouattara, ${ }^{*}$ N. Bissonnette, ${ }^{*}$ D. Pellerin, $\dagger$ J.-P. Laforest, $\dagger$ and C. L. Girard ${ }^{* 2}$ \\ *Agriculture et Agroalimentaire Canada, Centre de Recherche et Développement de Sherbrooke, Sherbrooke, Québec, J1M 0C8, Canada \\ †Département des Sciences Animales, Université Laval, Québec, G1V 0A6, Canada
}

\begin{abstract}
This study was undertaken to evaluate the effect of supplementation of folic acid and vitamin $\mathrm{B}_{12}$ on glucose and propionate metabolism. Twenty-four multiparous cows were assigned according to a complete block design in a $2 \times 2$ factorial arrangement to one of the following treatments: (1) saline $0.9 \% \mathrm{NaCl}$, (2) $320 \mathrm{mg}$ of folic acid, (3) $10 \mathrm{mg}$ of vitamin $\mathrm{B}_{12}$, or (4) $320 \mathrm{mg}$ of folic acid and $10 \mathrm{mg}$ of vitamin $\mathrm{B}_{12}$. Intramuscular injections were given weekly from $3 \mathrm{wk}$ before the expected calving date until 9 wk postpartum. At $63 \mathrm{~d}$ in milk, D- $\left[6,6{ }^{2} \mathrm{H}_{2}\right]$-glucose $(16.5 \mathrm{mmol} / \mathrm{h}$; jugular vein) and $\left[1-{ }^{13} \mathrm{C}\right]$-sodium propionate $(13.9 \mathrm{mmol} / \mathrm{h}$; ruminal vein) were simultaneously infused for $4 \mathrm{~h}$; blood samples were collected from 2 to $4 \mathrm{~h}$ of the infusion period. Liver biopsies were carried out the following day. Supplements of folic acid and vitamin $\mathrm{B}_{12}$ respectively increased folate and vitamin $\mathrm{B}_{12}$ concentrations, both in milk and liver. Although dry matter intake was unaffected by treatments, milk and milk lactose yields tended to be lower by 5.0 and by $0.25 \mathrm{~kg} / \mathrm{d}$, respectively, for cows receiving the folic acid supplement. Plasma $\beta$-hydroxybutyrate concentration with the folic acid supplement followed the same tendency. Hepatic gene expression of methylmalonyl-CoA mutase and S-adenosylhomocysteine hydrolase was higher for cows receiving the combined folic acid and vitamin $\mathrm{B}_{12}$ supplement compared with cows receiving only the supplement of folic acid, whereas no treatment effect was noted for cows not receiving the folic acid supplement. Whole-body glucose rate of appearance and the proportion of whole-body glucose rate of appearance secreted in milk lactose decreased by $229 \mathrm{~g} / \mathrm{d}$ and $5 \%$, respectively, for animals receiving the folic acid supplement, concomitant with the lower milk lactose

Received April 20, 2017

Accepted June 17, 2017.

${ }^{1}$ Current address: Centre de Recherche et Développement de Sherbrooke, Sherbrooke, Québec, J1M 0C8, Canada.

${ }^{2}$ Corresponding author: Christiane.Girard@agr.gc.ca
\end{abstract}

synthesis in these cows, indicating that supplementary folic acid may alter energy partitioning in cows. The absence of treatment effect on plasma concentrations of methylmalonic acid as well as on the proportion of glucose synthesized from propionate, averaging $60 \%$, supports the fact that vitamin $B_{12}$ supply was sufficient in control cows in the current study. Our results suggest that the folic acid supplement reduced glucose-derived lactose synthesis by redirecting glucose for other metabolic activity in the mammary gland or in other tissues. Key words: dairy cow, folic acid, vitamin $\mathrm{B}_{12}$, propionate, glucose

\section{INTRODUCTION}

The transition from late gestation to early lactation represents a challenge for high-yielding dairy cows. Major metabolic, physiological, and nutritional changes occur at parturition and the onset of lactation (Goff and Horst, 1997). Detrimental health effects may be induced by excessive negative energy balance in dairy cows coping with this challenging period (McArt et al., 2013). Previous studies concluded that a combined supplement of folic acid and vitamin $\mathrm{B}_{12}$ seems to improve the efficiency of energy metabolism in early lactation (Girard and Matte, 2005; Graulet et al., 2007; Preynat et al., 2009b) as suggested by the enhancement of lactational performance without a DMI increase for cows receiving the combined vitamin supplement.

In lactating cows, approximately $20 \%$ of glucose supply is provided through glucose absorption into the hepatic portal vein following starch digestion, whereas the remaining originates from gluconeogenesis (Galindo et al., 2011). In fed cows, propionate is the major precursor of glucose and liver removal of propionate contributes up to $60 \%$ of glucose hepatic release (Reynolds, 2006; Larsen and Kristensen, 2013). Before entering into the Krebs cycle, propionate needs to be transformed into propionyl-CoA, then into methylmalonyl-CoA, and, finally, into succinyl-CoA (Scott, 1999; Preynat et al., 2010). The latter transformation is vitamin $B_{12^{-}}$ dependent, the vitamin playing a role of coenzyme for 
methylmalonyl-CoA mutase (EC 5.4.99.2). In case of a vitamin $\mathrm{B}_{12}$ deficiency, methylmalonyl-CoA accumulates and is instead converted into methylmalonic acid (Scott, 1999).

In a previous study, increased plasma glucose was observed for multiparous cows in early lactation receiving a combined dietary supplement of folic acid and vitamin $\mathrm{B}_{12}$, whereas no effect was noted for cows receiving only a vitamin $B_{12}$ supplement (Graulet et al., 2007). Moreover, in multiparous cows at 87 DIM, weekly intramuscular injections of a combined supplement of folic acid and vitamin $\mathrm{B}_{12}$ increased the rate of appearance (Ra) of glucose by $160 \mathrm{~g} / \mathrm{d}$ (Preynat et al., 2009a). The glucose Ra represents the sum of glucose entry rates into the plasma pool from portal absorption, glycogenolysis, and gluconeogenesis. Preynat et al. (2009a) hypothesized that this increase was likely due to an enhanced gluconeogenesis caused by the combined vitamin supplement. Differences in glucose absorption and glycogenolysis were discarded as being the cause of the increased glucose Ra as DMI was similar between treatments and no study reports an effect of a combined supplement of folic acid and vitamin $\mathrm{B}_{12}$ on glycogen kinetics (Preynat et al., 2009a).

Vitamin $\mathrm{B}_{12}$ also acts as a coenzyme in the methylation cycle (Figure 1) and is closely interrelated with folate metabolism. Indeed, 5-methyl-tetrahydrofolate, the methylated form of folic acid, can give its methyl group to homocysteine (Hcy) to form Met using vitamin $B_{12}$ as a coenzyme of Met synthase (EC 2.1.1.13). Methionine could be used to form proteins or could be transformed into S-adenosylmethionine, which is the major methyl donor in mammals (Scott, 1999). After its demethylation, tetrahydrofolate might be involved in purine and pyrimidine syntheses, both DNA components. Consequently, a lack of folic acid and vitamin $\mathrm{B}_{12}$ impedes cell division (Scott, 1999).

It was hypothesized that increasing folic acid and vitamin $B_{12}$ supplies would facilitate propionate entering into the Krebs cycle and then would increase gluconeogenesis. This study was undertaken to evaluate whole-body (WB) kinetics of glucose and propionate and the proportion of glucose synthesized from propionate at 9 wk of lactation following a supplementation of

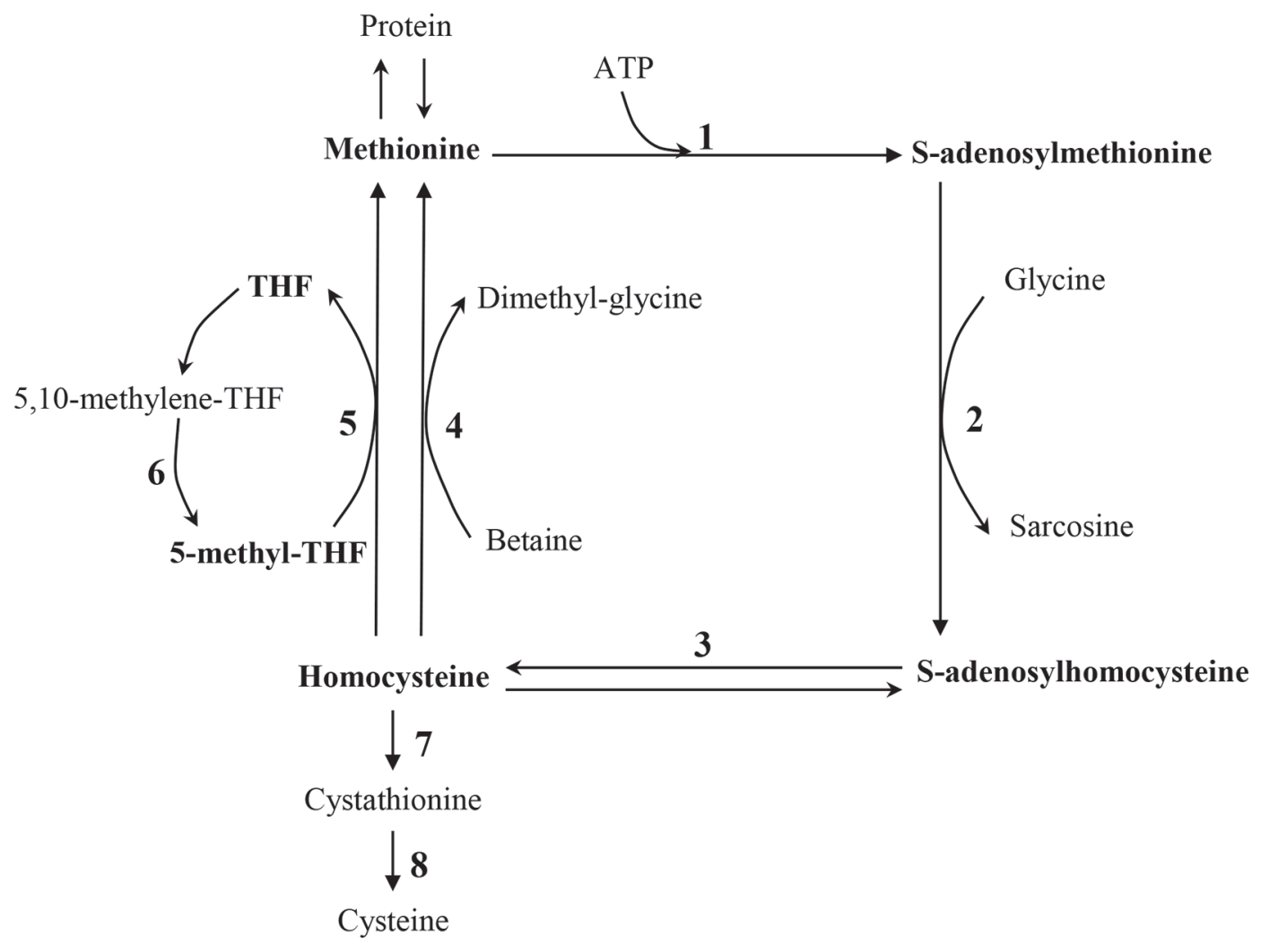

Figure 1. Simplified metabolic pathways involving folic acid and vitamin $B_{12}$. Enzymes: $1=$ methionine adenosyltransferase; $2=$ glycine $N$-methyltransferase; 3 = adenosylhomocysteinase; $4=$ betaine homocysteine methyltransferase; $5=$ methionine synthase and vitamin $\mathrm{B}_{12}$ as a coenzyme; $6=5,10$-methylenetetrahydrofolate reductase; $7=$ cystathionine $\beta$-synthase; and $8=$ cystathionine $\beta$-lyase (adapted from Preynat et al., 2010). THF = tetrahydrofolate. 
folic acid and vitamin $\mathrm{B}_{12}$, alone or combined, given by weekly intramuscular injections from $3 \mathrm{wk}$ prepartum to $9 \mathrm{wk}$ postpartum. This experiment allowed studying the influence of folic acid supplementation on the effect of vitamin $B_{12}$ supplementation on the above cited propionate metabolic pathway. Moreover, plasma concentrations of AA and metabolites and hepatic gene expression closely related to the methylation cycle and propionate pathway were measured to better characterize the effects of these vitamin supplements in dairy cows.

\section{MATERIALS AND METHODS}

\section{Cows and Treatments}

Twenty-four multiparous Holstein cows from the dairy herd at the Agriculture and Agri-Food Canada Research Centre (Sherbrooke, QC, Canada) were enrolled in this experiment as previously described by Duplessis et al. (2017). Briefly, animals were kept in a tie-stall barn and milked twice daily in a milking parlor at 12 -h intervals under $1830 \mathrm{~h}$ of light per d. Cows were assigned to 6 blocks of 4 animals each according to their previous 305-d milk production to one of the following treatments: (1) saline $0.9 \% \mathrm{NaCl}\left(\mathbf{B}_{9}-\mathbf{B}_{12}-\right)$; (2) $320 \mathrm{mg}$ of folic acid $\left(\mathbf{B}_{9}+\mathbf{B}_{12}-\right.$; pteroylmonoglutamic acid, MP Biomedicals, Solon, OH); (3) $10 \mathrm{mg}$ of vitamin $\mathrm{B}_{12}\left(\mathbf{B}_{\mathbf{9}}-\mathbf{B}_{12}+\right.$; cyanocobalamin, $5,000 \mu \mathrm{g} / \mathrm{mL}$, Vétoquinol, Lavaltrie, QC, Canada); or (4) $320 \mathrm{mg}$ of folic acid and $10 \mathrm{mg}$ of vitamin $\mathrm{B}_{12}\left(\mathbf{B}_{\mathbf{9}}+\mathbf{B}_{12}+\right)$. Intramuscular injections of $5 \mathrm{~mL}$ were administered weekly from 3 wk before the expected calving date until $9 \mathrm{wk}$ of lactation. The parenteral route was chosen instead of dietary supplementation as it has been shown that the utilization and destruction of these vitamins by the rumen microorganisms are large (Santschi et al., 2005).

Lactational performance and energy status of cows from the current study from $3 \mathrm{wk}$ before calving until 7 wk of lactation have been previously reported (Duplessis et al., 2017). Briefly, cows receiving folic acid supplement produced similar milk total solid yield, had lower plasma nonesterified fatty acid (NEFA) concentration and BCS losses, and higher plasma glucose and insulin concentrations than cows that did not, suggesting that supplementary folic acid altered energy partitioning in early lactation. Hepatic and mammary tissue gene expression for these cows at wk 9 of lactation has also been presented elsewhere (Ouattara et al., 2016).

Before parturition, a precalving diet $(\mathrm{CP}=14.7 \%$ $\mathrm{DM} ; \mathrm{NE}_{\mathrm{L}}=1.51 \mathrm{Mcal} / \mathrm{kg}$ of DM; $\mathrm{NDF}=39.2 \% \mathrm{DM}$; $\mathrm{Co}=1.45 \mathrm{mg} / \mathrm{kg}$ of $\mathrm{DM}$ ) was fed to dairy cows and a lactation diet was offered postpartum $(\mathrm{CP}=17.3 \%$
$\mathrm{DM} ; \mathrm{NE}_{\mathrm{L}}=1.65 \mathrm{Mcal} / \mathrm{kg}$ of $\mathrm{DM} ; \mathrm{NDF}=26.6 \% \mathrm{DM}$; Co $=1.05 \mathrm{mg} / \mathrm{kg}$ of DM; Duplessis et al., 2017). Daily intake and orts for each cow were weighed and feed offered was adjusted if needed allowing 10\% refusals. Cows had free access to water. Six d before the infusions of labeled glucose and propionate, beginning approximately at 8 wk of lactation, 12 equal meals per day were given every $2 \mathrm{~h}$ to dairy cows using automated feeders (Ankom, Fairport, NY) to minimize postprandial variations during the measurements of WB glucose and propionate Ra. Care of cows followed the guidelines of the National Farm Animal Care Council (2009). All procedures were approved by the Institutional Committee on Animal Care of the Research Center according to the guidelines of the Canadian Council on Animal Care (2009).

\section{Surgery}

A surgery to insert a catheter (Tygon Microbore Tubing, Formula S-54-HL, Saint-Gobain Performance Plastics, Courbevoie, France) into a ruminal vein for performing the infusion of labeled propionate was carried out at $54 \pm 2$ DIM. The day before the surgery, a catheter was inserted into each jugular vein: one for labeled glucose infusion and one for blood sampling. Two days and $1 \mathrm{~d}$ before the surgery, $2 / 3$ and $1 / 3$, respectively, of the TMR intake was offered to the cows and water access was cut off $12 \mathrm{~h}$ before the surgery. The night before the surgery, a solution of ultra-pure water $(19.0 \mathrm{~L}), \mathrm{NaCl}(90.0 \mathrm{~g})$, and dextrose $50 \%(1.0$ $\mathrm{L})$ was infused in 1 jugular vein. At least $30 \mathrm{~min}$ before the surgery, $40 \mathrm{~mL}$ of penicillin $\mathrm{G}$ procaine $(300,000 \mathrm{IU}$ of penicillin G/mL; Zoetis Canada Inc., Kirkland, QC, Canada) and $20 \mathrm{~mL}$ of ketoprofen (100 $\mathrm{mg}$ of ketoprofen/mL; Merial Canada Inc., Baie-d'Urfé, QC, Canada) were injected i.m.

The surgery was done under paravertebral anesthesia on the left side of the standing cow. A skin incision of 20 to $30 \mathrm{~cm}$ was performed on the ventral part of the paralumbar fossa. After incising muscles and peritoneum, the dorsal sack of the rumen was exteriorized to localize 1 ruminal vein. On average, a catheter length of $40 \mathrm{~cm}$ was inserted into 1 left ruminal vein. The catheter was then exteriorized between left transverse processes of lumbar vertebras 3-4 or 4-5. Immediately after the surgery, cows had free access to water and hay was offered. A few hours after the surgery, half of the TMR previous intake was offered. A solution of ultra-pure water $(19.0 \mathrm{~L}), \mathrm{NaCl}(110.0 \mathrm{~g}), \mathrm{KCl}(30.0 \mathrm{~g})$, dextrose $50 \%(0.5 \mathrm{~L})$, and calcium borogluconate $23 \%$ $(0.5 \mathrm{~L})$ was infused in 1 jugular vein to help the cows recovering from the surgery. During the $2 \mathrm{~d}$ following 
the surgery, cows received intramuscular injections of $40 \mathrm{~mL}$ of procainic penicillin $\mathrm{G}$ twice per day and 20 $\mathrm{mL}$ of ketoprofen once per day.

\section{Sampling and Measurements}

Blood. Blood samples were taken at $61 \pm 3$ DIM at $1315 \mathrm{~h}$ by venipuncture of the coccygeal vein using a vacutainer system (Becton, Dickinson and Co., Franklin Lakes, NJ) and were treated as described by Duplessis et al. (2017). Blood was collected in tubes with EDTA to determine plasma folates, vitamin $\mathrm{B}_{12}$, NEFA, and BHB concentrations and in heparinized tubes for plasma glucose, insulin, methylmalonic acid, urea, and AA concentrations.

$\boldsymbol{B} \boldsymbol{W}$ and $\boldsymbol{B} \boldsymbol{C S}$. Cows were weighed after the morning milking for 2 consecutive d at 70 and $71 \pm 3$ DIM. Average BW for those 2 consecutive $\mathrm{d}$ was used for statistical analysis. Body condition scores were done by the same individual at $61 \pm 3$ DIM according to a 1 (very thin) to 5 (very fat) scale using quarter points (Wildman et al., 1982; Ferguson et al., 1994).

Milk. Milk yields were recorded at each milking the week before the tracer infusion (i.e., between 56 and 63 DIM and daily yields were averaged for the whole week). Milk samples were taken from 2 consecutive milkings before performing tracer infusions at $62 \pm 3$ DIM.

\section{Blood and Milk Analyses}

Blood. Plasma concentrations of folates, vitamin $\mathrm{B}_{12}$, glucose, insulin, $\mathrm{BHB}$, NEFA, and urea were analyzed using commercial kits as previously described by Duplessis et al. (2017). Plasma concentrations of methylmalonic acid and AA were analyzed by GC-MS (model CG6890-MS5973, Hewlett Packard Co., Wilmington, DE) in electron ionization mode as described by Duplessis et al. (2017).

Milk. Milk composition (fat, protein, and lactose) was analyzed by Valacta (Dairy Production Center of Expertise, Québec and Atlantic Provinces, SainteAnne-de-Bellevue, QC, Canada) using mid-infrared reflectance spectrometry (MilkoScan FT 6000, Foss, Hillerød, Denmark). Milk fat, protein, and lactose yields were computed from average milk yields the week before the tracer infusion multiplied by respective milk component concentrations. Folates and vitamin $\mathrm{B}_{12}$ in milk were analyzed in duplicate by RIA using a commercial kit (SimulTRAC $\mathrm{B}_{12}$ /Folate-S, MP Biomedicals) as described previously (Duplessis et al., 2015). The interassay CV were 2.3 and $1.7 \%$ for folate and vitamin $\mathrm{B}_{12}$ analyses, respectively.
Tracer Infusions. At $63 \pm 3$ DIM, D- $\left[6,6{ }^{2} \mathrm{H}_{2}\right]-$ glucose (99 mol percent excess; Cambridge Isotope Laboratories Inc., Andover, MA) at a rate of $16.5 \pm 0.4$ $\mathrm{mmol} / \mathrm{h}$ and $\left[1-{ }^{1 \mathrm{~d} 3} \mathrm{C}\right]$-sodium propionate $(99 \mathrm{~mol}$ percent excess; Cambridge Isotope Laboratories Inc.) at a rate of $13.9 \pm 0.4 \mathrm{mmol} / \mathrm{h}$ were simultaneously infused in 1 jugular vein and 1 ruminal vein, respectively, using a syringe pump. Tracers were previously dissolved in sterile saline. Infusions began on average at $0930 \mathrm{~h}, 90$ min after a meal, and lasted $4 \mathrm{~h}$.

Blood Sampling. The day of tracer infusions, 1 blood sample was collected on average $1 \mathrm{~h}$ before the initiation of infusions to determine isotopic natural abundance. Two hours following the beginning of the labeled glucose and propionate infusions, blood samples were taken every 15 min from the contralateral jugular catheter for the next $2 \mathrm{~h}(\mathrm{n}=9)$ and placed in heparinized vacutainer tubes (Becton, Dickinson and Co., Franklin Lakes, NJ). Tubes were kept on ice until centrifugation and were centrifuged within 60 min after collection at $3,000 \times g$ and $4^{\circ} \mathrm{C}$ for $15 \mathrm{~min}$. Aliquots of plasma were transferred into $2-\mathrm{mL}$ tubes and stored at $-80^{\circ} \mathrm{C}$ until analysis.

Enrichment Analyses. The isotopic enrichment of glucose was performed with GC-MS (model CG6890MS5973N, Hewlett Packard Co.) as described by Preynat et al. (2009a) in the positive chemical ionization mode. The isotopic enrichment of glucose isotopomers were assessed by monitoring ions at $m / z 331,332$, and 333 to quantify isotopic enrichment of $\mathrm{m}+1$ and $\mathrm{m}+2$.

Propionate isotopic enrichment was measured using a GC-MS (model CG6890-MS5973N, Hewlett Packard Co.) with mass selective detector operating in the positive chemical ionization mode. Plasma $(500 \mu \mathrm{L})$ was first deproteinized with $0.2 \mathrm{~g}$ of 5 -sulfosalicylic acid hydrate (Thermo Fisher Scientific, Waltham, MA) vortexed for $1 \mathrm{~min}$ and then centrifuged at $16,200 \times g$ for $5 \mathrm{~min}$ at $4^{\circ} \mathrm{C}$. Supernatants were collected, $1.5 \mathrm{~mL}$ of ethyl ether was added into 2-mL Eppendorf tubes, and the mixture was vortexed 5 times before a centrifugation at 16,200 $\times g$ for $2 \mathrm{~min}$ at $4^{\circ} \mathrm{C}$. Supernatants were transferred into a 2-mL Eppendorf tubes with Drierite in the bottom (calcium sulfate, W. A. Hammond Drierite Co. Ltd., Xenia, OH), kept at room temperature for $2 \mathrm{~h}$, and frequently shaken. Two hours later, tubes were centrifuged at $16,200 \times g$ for 2 min at $4^{\circ} \mathrm{C}$. A total of $60 \mu \mathrm{L}$ of acetonitrile mixed with sodium sulfate was pipetted into 2 -mL glass vials (reacti-Vial) and a pen mark was made at the level of the sodium sulfate acetonitrile blend on the vial. Supernatants from the last centrifugation were transferred into the glass vials, which were capped and then vortexed. Samples were then evaporated under $\mathrm{N}$ using a multineedle manifold 
(Reacti-Therm III, Heating module, Pierce, Rockford, IL) until the volume decreased to the pen mark on the glass vials. A total of $10 \mu \mathrm{L}$ of $N$-tert-butyldimethylsilyl$\mathrm{N}$-methyltrifluoroacetamide (Sigma-Aldrich, Oakville, ON, Canada) was added and samples were heated at $60^{\circ} \mathrm{C}$ for $10 \mathrm{~min}$ and analyzed for isotopic enrichment by monitoring ions at $m / z 131$ and 132 .

\section{Calculations}

Glucose and propionate isotopic enrichment are expressed as mole percent excess. Whole-body glucose and propionate Ra were computed as follows: $\mathrm{Ra}(\mathrm{mmol} / \mathrm{h})$ $=$ (infusion rate/isotopic enrichment) - infusion rate where infusion rate is expressed in millimoles per hour. For WB glucose Ra, the calculation was made using the isotopic enrichment of the infused molecule (i.e., $\mathrm{m}+2$ glucose isotopomer). The proportion of glucose synthesized from propionate was obtained as follows: $\%$ of glucose synthesized from propionate $=(\mathrm{m}+1$ glucose isotopic enrichment/propionate isotopic enrichment) $x$ 2 . This factor 2 was used to take into account that half of the labeled $\mathrm{C}$ from $\left[1-{ }^{13} \mathrm{C}\right]$-sodium propionate would be lost as $\mathrm{CO}_{2}$ out of the mitochondria during the transformation of malate into oxaloacetate, then into phosphoenolpyruvate to form glucose (Mayes, 1981). Glucose flux from propionate $(\mathrm{mmol} / \mathrm{h})$ was calculated by multiplying the percentage of glucose synthesized from propionate by WB glucose Ra.

\section{Liver Biopsies and Analyses}

Liver biopsies were performed at $64 \pm 3$ DIM according to the procedure previously described by Graulet et al. (2007). Briefly, liver biopsies were done at the level of the 10th intercostal space under local anesthesia by a veterinarian under ultrasound guidance. On average, 1,658 $\pm 338 \mathrm{mg}$ of liver tissue was taken off. The samples were blotted to remove excess blood and connective tissue before being frozen in liquid $\mathrm{N}$ and stored at $-80^{\circ} \mathrm{C}$ until analysis.

Folates and Vitamin $\boldsymbol{B}_{12}$. Methods for folate and vitamin $\mathrm{B}_{12}$ analyses in liver were previously described by Graulet et al. (2007). About 40 and $30 \mathrm{mg}$ of frozen liver samples were used for folate and vitamin $\mathrm{B}_{12}$ quantifications, respectively. Commercial kits designed for human plasma were used to determine hepatic concentrations of folic acid and vitamin $\mathrm{B}_{12}$ by RIA (SimulTRAC B ${ }_{12}$ /Folate-S, MP Biomedicals).

Total RNA Isolation and Purification. Total RNA was extracted from hepatic tissue by using a QIAzol Lysis Reagent (Qiagen, Toronto, ON, Canada) following the original manufacturer protocol with slight modifications. Briefly, frozen samples (100 mg of liver tissue) were homogenized in $2 \mathrm{~mL}$ of QIAzol Lysis Reagent on ice using a tissue-tearor homogenizer. A volume of $600 \mu \mathrm{L}$ of QIAzol Lysis Reagent was added to $400 \mu \mathrm{L}$ of homogenate; the mixture was vigorously vortexed and kept at room temperature for $5 \mathrm{~min}$ to promote dissociation of nucleoprotein complexes. A volume of $200 \mu \mathrm{L}$ of chloroform was added; the mixture was shaken and left at room temperature for $3 \mathrm{~min}$ followed by a centrifugation at 12,000 $\times g$ for 15 min at $4^{\circ} \mathrm{C}$ to remove lipids. After centrifugation, the aqueous fraction which contained RNA was carefully pipetted, and RNA was precipitated by adding an equal volume of $70 \%$ ethanol and mixed thoroughly by vortexing. The RNA was then purified using RNeasy Mini Kit (Qiagen), including on-column DNase digestion.

Quantitative Real-Time PCR. Quantifications by real-time PCR following reverse transcription were performed as previously described by Lévesque-Sergerie et al. (2007) with minor modifications (Dudemaine et al., 2014). Table 1 provides primer sequences and optimal conditions for PCR of studied genes. The real timePCR reactions (10 $\mu \mathrm{L}$, final volume) were performed on 96-well plates using Fast SYBR Green PCR Master Mix (Life Technologies, Burlington, ON, Canada) in a 7500 Fast Real Time-PCR System (Life Technologies). The expression of 5 reference genes, namely $\beta$-actin $(A C T B)$, peptidylprolyl isomerase A (PPIA), GAPDH, ubiquitously expressed transcript $(U X T)$, tyrosine 3-monooxygenase/tryptophan 5-monooxygenase activation protein, zeta polypeptide ( $Y W H A Z$ ), was determined for all samples. The geometrical mean of $A C T B$ and PPIA were selected using NormFinder (Andersen et al., 2004) for normalization as their stability variances presented the lowest values.

Methylmalonyl-CoA Mutase Activity. Determination of hepatic total activity of methylmalonyl-CoA mutase and holomutase were performed as described by Ouattara et al. (2013) with a reversed-phase HPLC method.

\section{Statistical Analysis}

Two levels of folic acid ( 0 or $320 \mathrm{mg} / \mathrm{wk}$ ) and 2 levels of vitamin $\mathrm{B}_{12}(0$ or $10 \mathrm{mg} / \mathrm{wk})$ were tested in a $2 \times 2$ factorial arrangement in a 6-randomized block design. Daily milk yield and DMI were averaged for the week before tracer infusions. All variables were analyzed using the MIXED procedure of SAS (version 9.4 SAS Institute Inc., 2012). Fixed effects were folic acid, vitamin $\mathrm{B}_{12}$, blocks, as well as folic acid $\times$ vitamin $\mathrm{B}_{12}$ interaction. Results were considered significant when $P$ $\leq 0.05$ and as a tendency at $0.05<P \leq 0.10$. When the interaction folic acid $\times$ vitamin $B_{12}$ was significant or a tendency, the SLICE option in the LSMEANS 
Table 1. Primer sequences for PCR analysis of studied genes of dairy cows

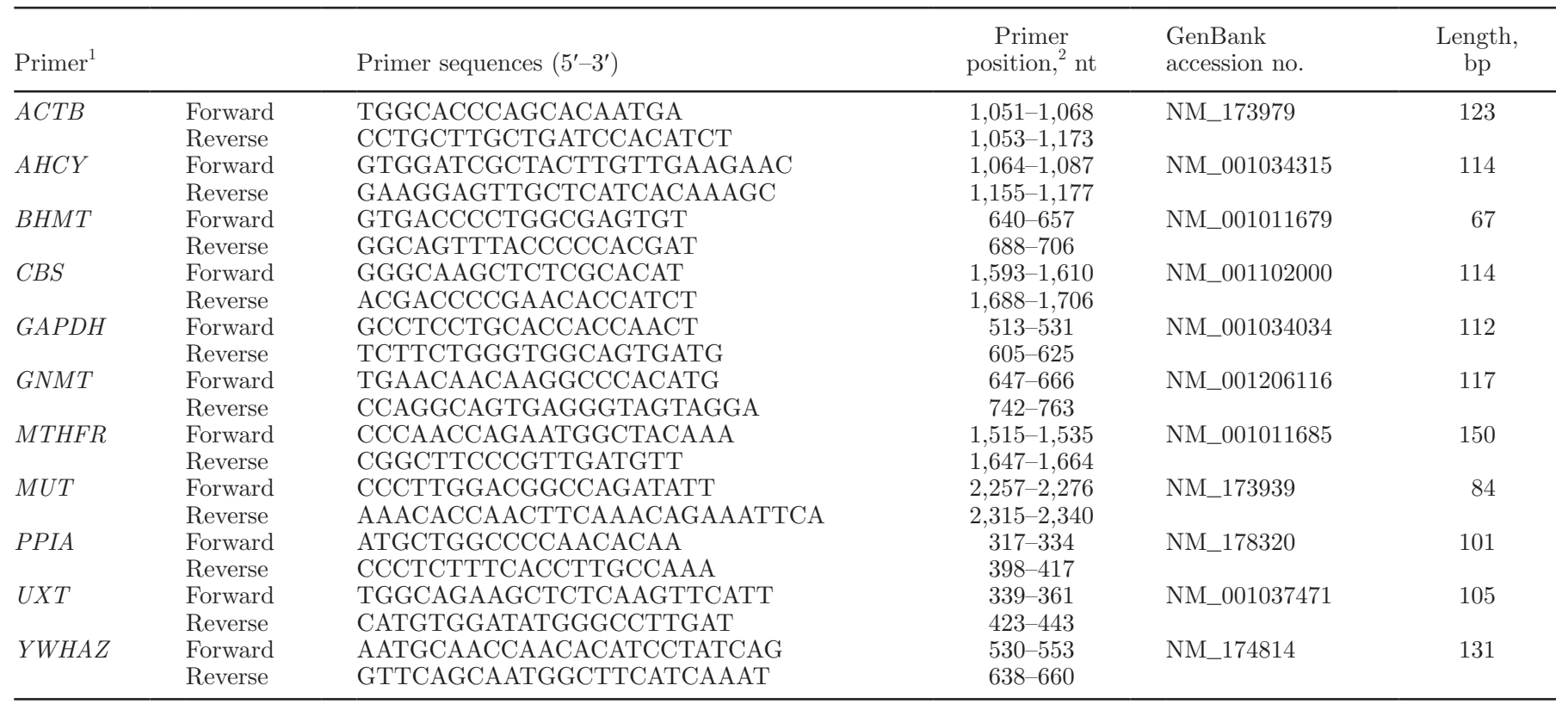

${ }^{1} A C T B=\beta$-actin; $A H C Y=$ S-adenosylhomocysteine hydrolase; $B H M T=$ betaine homocysteine methyltransferase; $C B S=$ cystathionine $\beta$-synthase; $G N M T=$ glycine $N$-methyltransferase; $M T H F R=5,10$-methylene-tetrahydrofolate reductase; $M U T=$ methylmalonyl-CoA mutase; $P P I A=$ peptidylprolyl isomerase A; $U X T=$ ubiquitously expressed transcript; $Y W H A Z=$ tyrosine 3-monooxygenase/tryptophan 5-monooxygenase activation protein, zeta polypeptide.

${ }^{2}$ Positions refer to the GenBank accession number.

statement of SAS was used to help interpret results. The insertion of the catheter into the ruminal vein was not possible for 1 cow due to a problem with the ruminal vein conformation and the ruminal catheter was not working for 1 cow the day of infusion. For these 2 cows $\left(\mathrm{B}_{9}+\mathrm{B}_{12}+\right)$, only data from labeled glucose infusion were used in the analysis. One cow $\left(\mathrm{B}_{9}+\mathrm{B}_{12}-\right)$ was not included in the statistical analyses for WB kinetics because her DMI the day of tracer infusions was $5.8 \mathrm{~kg}$, which was on average lower by $15.0 \mathrm{~kg}$ than the DMI of other cows the day of infusions. Liver sample from 1 control cow $\left(\mathrm{B}_{9}-\mathrm{B}_{12^{-}}\right)$was not sufficient to perform folate and vitamin $\mathrm{B}_{12}$ analyses.

\section{RESULTS AND DISCUSSION}

\section{Production Data}

Dry matter intake, BW, and BCS were not different among treatments at wk 9 postpartum $(P \geq 0.30$; Table 2) as previously observed (Girard and Matte, 2005; Graulet et al., 2007; Preynat et al., 2009a,b) with supplementation of these $\mathrm{B}$ vitamins. At wk 9 of lactation, milk yield tended to be lower by $5.0 \mathrm{~kg} / \mathrm{d}$ for cows receiving the folic acid supplement compared with cows that did not receive it $(P=0.10$; Table 2$)$. In contrast, Preynat et al. (2009a) reported that, at wk 12 postpar- tum, a supplementation of folic acid plus vitamin $B_{12}$ increased milk yield by $12 \%$. Moreover, supplementary folic acid increased milk production by $3.4 \mathrm{~kg} / \mathrm{d}$ during the first 8 wk of lactation in a previous experiment (Graulet et al., 2007). No treatment effects were noted on milk concentrations of fat, protein, lactose, and TS and milk yields of fat, protein, and TS $(P \geq 0.11$; Table 2 ). The tendency for a decrease in milk lactose yield by $0.25 \mathrm{~kg} / \mathrm{d}$ for cows receiving the folic acid supplement $(P=0.07$; Table 2$)$ could explain the decrease in milk production at wk 9 .

The supplement of folic acid increased milk concentration of folates $(P=0.01$; Table 2$)$ but did not increase the amounts of folates secreted daily in milk $(P=0.36$; Table 2). Graulet et al. (2007) reported an increase of both milk concentration and yield of folates, whereas Preynat et al. (2009b) only observed an augmentation of the amounts of folates secreted daily in milk following supplementary folic acid. Milk concentration and yield of vitamin $\mathrm{B}_{12}$ were increased by the vitamin $\mathrm{B}_{12}$ supplement $(P<0.0001$; Table 2$)$ as frequently reported in the literature (Girard and Matte, 2005; Graulet et al., 2007; Akins et al., 2013). In addition, in the current study, vitamin $\mathrm{B}_{12}$ concentration of milk was greater by $1,814 \mathrm{pg} / \mathrm{mL}$ for cows receiving the folic acid supplement compared with cows that did not $(P=0.05 ;$ Table 2$)$. 


\section{Plasma Variables}

An interaction folic acid $\times$ vitamin $\mathrm{B}_{12}$ was observed on plasma concentration of folates $(P=0.05$; Table $3)$. However, results from the SLICE option of SAS indicated no significant effect of folic acid within each level of vitamin $\mathrm{B}_{12}$ supplementation $(P \geq 0.11)$. At wk 9 postpartum, plasma concentration of folates was unaffected by folic acid supplement $(P=0.92$; Table 3 ) and averaged $18.4 \pm 1.6 \mathrm{ng} / \mathrm{mL}$, in line with observations made in the same cows from wk 4 to 7 of lactation (Duplessis et al., 2017) and at wk 12 of lactation in another study (Preynat et al., 2009a). Plasma concentration of vitamin $\mathrm{B}_{12}$ was higher $(P=0.04)$ for cows receiving the vitamin $\mathrm{B}_{12}$ supplement than for cows that did not (417 vs. $320 \pm 30 \mathrm{pg} / \mathrm{mL}$; Table 3 ) as similarly reported by Graulet et al. (2007), Preynat et al. (2009b), and Akins et al. (2013).

Plasma concentrations of glucose, insulin, NEFA, methylmalonic acid, urea, Ala, Glu, Gly, Ile, Leu, Lys, Met, Phe, Pro, Ser, Trp, Tyr, Val, branched-chain AA, EAA, and NEAA, and total AA were unaffected by treatments at wk 9 postpartum $(P \geq 0.11$; Table 3). Plasma concentration of methylmalonic acid was lower, even in control cows, than reported by Girard and Matte (2005), which suggests that the vitamin $\mathrm{B}_{12}$ supply was sufficient to avoid a negative effect on methylmalonyl-CoA mutase activity. Plasma concentration of BHB tended to decrease from 0.76 to 0.61 $\pm 0.06 \mathrm{~m} M$ with the folic acid supplement $(P=0.09$; Table 3). The supplement of vitamin $\mathrm{B}_{12}$ tended to increase plasma concentrations of Asn and Gln $(P \leq$ 0.08; Table 3). Plasma concentration of Asp decreased $(P=0.006)$, whereas plasma concentrations of His and Hcy increased with the folic acid supplement $(P=0.04$; Table 3). The highest plasma concentrations of Cys and Thr were observed for cows receiving the combined supplement of folic acid and vitamin $\mathrm{B}_{12}(P \leq 0.10)$. Regardless of treatments, plasma concentration of Met was higher than in the trials of Graulet et al. (2007) and Preynat et al. (2009a).

\section{Liver Variables}

B Vitamins. Liver concentration of folates was increased by $13.9 \mu \mathrm{g} / \mathrm{g}$ of fresh tissue by the folic acid supplement $(P<0.0001$; Table 4$)$. Graulet et al. (2007) and Preynat et al. (2010) also reported that a folic acid supplement increased hepatic concentration of folates. Compared with the study of Preynat et al. (2010), liver concentrations of folates in the current experiment were greater by $202 \%$ for cows receiving the folic acid supplement. However, it is noteworthy that, in the present study, the weekly dose of the folic acid supplement was twice $(320 \mathrm{mg})$ the amount used in Preynat et al. (2010; $160 \mathrm{mg})$. Intramuscular injections of vitamin $\mathrm{B}_{12}$ increased liver concentration of vitamin $\mathrm{B}_{12}(P=0.007$;

Table 2. Effects of intramuscular injections of folic acid and vitamin $\mathrm{B}_{12}$ on DMI, BW, BCS, and milk yield and components at wk 9 of lactation ${ }^{1}$

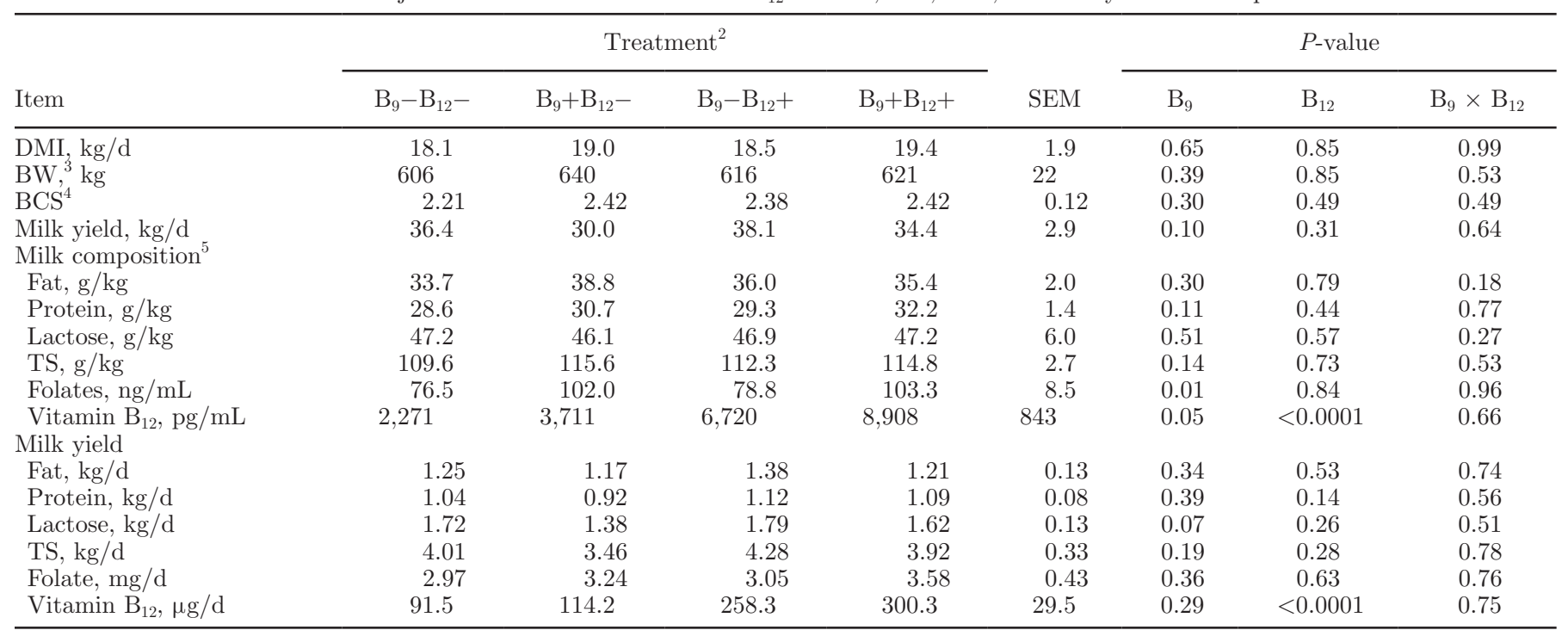

${ }^{1} \mathrm{LSM}$ with SEM, $\mathrm{n}=6$.

${ }^{2} \mathrm{~B}_{9}-\mathrm{B}_{12}-=$ no vitamin supplement; $\mathrm{B}_{9}+\mathrm{B}_{12}-=320 \mathrm{mg}$ of folic acid; $\mathrm{B}_{9}-\mathrm{B}_{12}+=10 \mathrm{mg}$ of vitamin $\mathrm{B}_{12} ; \mathrm{B}_{9}+\mathrm{B}_{12}+=320 \mathrm{mg}$ of folic acid and $10 \mathrm{mg}$ of vitamin $\mathrm{B}_{12}$ given weekly from $3 \mathrm{wk}$ before the expected calving date until $9 \mathrm{wk}$ postpartum.

${ }^{3}$ Average BW at 70 and $71 \pm 3$ DIM.

${ }^{4}$ Data on BCS were measured at $61 \pm 3$ DIM according to a 1 to 5 scale with quarter points (Wildman et al., 1982; Ferguson et al., 1994).

${ }^{5}$ Data averaged from 2 consecutive milkings before tracer infusions. 
Table 4) as previously reported (Preynat et al., 2010; Akins et al., 2013).

Gene Expression. No treatment effect was observed on the hepatic gene expression of betaine homocysteine methyltransferase $(B H M T)$, cystathionine $\beta$-synthase $(C B S)$, glycine N-methyltransferase (GNMT), and 5,10-methylene-tetrahydrofolate reductase (MTHFR; $P$ $\geq 0.23$; Table 4 ). A folic acid $\times$ vitamin $\mathrm{B}_{12}$ interaction was observed on gene expression of S-adenosylhomocysteine hydrolase ( $A H C Y ; P=0.004$; Table 4); the highest $A H C Y$ expression was observed for cows receiving the combined supplement of folic acid and vitamin $\mathrm{B}_{12}$ compared with folic acid or vitamin $\mathrm{B}_{12}$ supplementation alone $(P \leq 0.009)$. In the methyla- tion cycle (Figure 1), AHCY is required to transform S-adenosylhomocysteine to Hcy (Finkelstein, 1990). The greatest $A H C Y$ expression for cows receiving the combined vitamin supplement is in accordance with the highest plasma concentration of Hcy and Cys observed in these cows at wk 9 of lactation but also within the first 7 wk postpartum (Duplessis et al., 2017). A tendency for a folic acid $\times$ vitamin $\mathrm{B}_{12}$ interaction on methylmalonyl-CoA mutase (MUT) expression was noted $(P=0.09$; Table 4$)$. Supplementary vitamin $\mathrm{B}_{12}$ increased $M U T$ expression when cows received the folic acid supplement $(P=0.04)$, whereas it had no effect when cows did not receive the folic acid supplement $(P=0.75)$. Indeed, the highest MUT expression

Table 3. Effects of intramuscular injections of folic acid and vitamin $\mathrm{B}_{12}$ on plasma concentrations of $\mathrm{B}$ vitamins, glucose, insulin, BHB, nonesterified fatty acids (NEFA), methylmalonic acid, urea, and AA at $61 \pm 3$ DIM $^{1}$

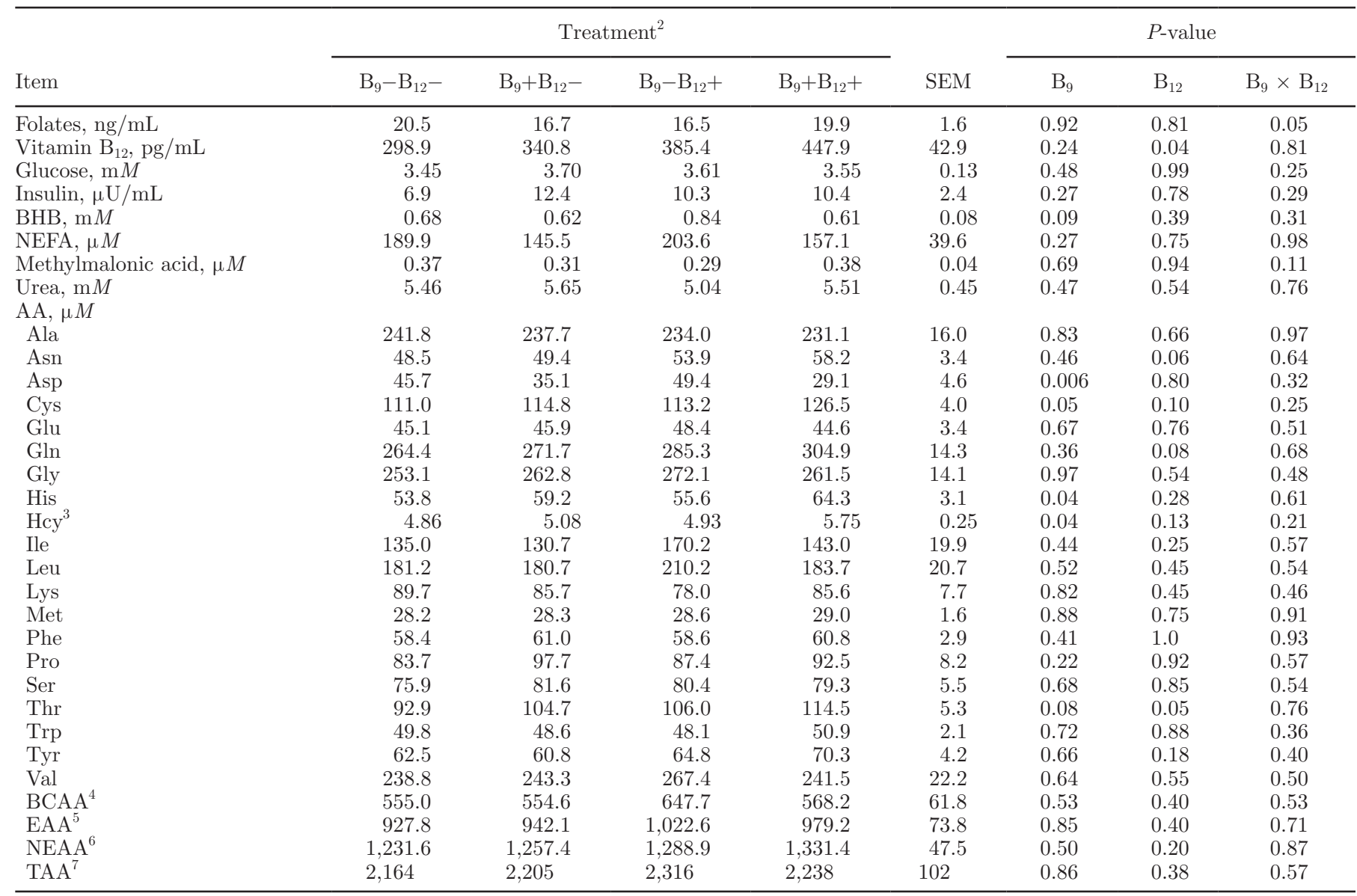

${ }^{1}$ LSM with SEM, $\mathrm{n}=6$.

${ }^{2} \mathrm{~B}_{9}-\mathrm{B}_{12}-=$ no vitamin supplement; $\mathrm{B}_{9}+\mathrm{B}_{12}-=320 \mathrm{mg}$ of folic acid; $\mathrm{B}_{9}-\mathrm{B}_{12}+=10 \mathrm{mg}$ of vitamin $\mathrm{B}_{12} ; \mathrm{B}_{9}+\mathrm{B}_{12}+=320 \mathrm{mg}$ of folic acid and $10 \mathrm{mg}$ of vitamin $\mathrm{B}_{12}$ given weekly from 3 wk before the expected calving date until 9 wk postpartum.

${ }^{3}$ Hcy $=$ homocysteine.

${ }^{4} \mathrm{BCAA}=$ branched-chain $\mathrm{AA}=\mathrm{Ile}+\mathrm{Leu}+$ Val.

${ }^{5} \mathrm{EAA}=\mathrm{His}+\mathrm{Ile}+\mathrm{Leu}+\mathrm{Lys}+\mathrm{Met}+\mathrm{Phe}+\mathrm{Thr}+\mathrm{Trp}+$ Val.

${ }^{6} \mathrm{NEAA}=\mathrm{Ala}+\mathrm{Asn}+\mathrm{Asp}+\mathrm{Cys}+\mathrm{Gln}+\mathrm{Glu}+\mathrm{Gly}+\mathrm{Pro}+\mathrm{Ser}+\mathrm{Tyr}$.

${ }^{7} \mathrm{TAA}=$ total AA. 
was obtained with the combined supplement of folic acid and vitamin $\mathrm{B}_{12}$ as in the study of Preynat et al. (2010). However, Graulet et al. (2007) did not report any treatment effect in early lactation on $M U T$ expression for cows receiving dietary folic acid and vitamin $\mathrm{B}_{12}$ supplement. The lowest hepatic concentration of vitamin $\mathrm{B}_{12}$ and $M U T$ expression were observed in cows receiving the folic acid supplement alone. In rat liver, Nakao et al. (2009) noted that mRNA level of MUT was decreased by a vitamin $\mathrm{B}_{12}$-deficient diet compared with a diet providing sufficient amount of vitamin $B_{12}$. In the current study, even though vitamin $B_{12}$ supply was probably not deficient for dairy cows receiving the folic acid supplement alone, it might explain the lower MUT expression observed for these cows as vitamin $\mathrm{B}_{12}$ concentration in liver was also lower than in other treatment groups.

Methylmalonyl-CoA Mutase Activity. As reported by Graulet et al. (2007), total methylmalonylCoA mutase specific activity was unaffected by supplementation of folic acid and vitamin $\mathrm{B}_{12}$ and averaged $14.39 \pm 0.71 \mathrm{nmol} / \mathrm{mg}$ of protein per $\min (P \geq 0.25$; Table 4). Holomutase activity, which represents the activity of the enzyme bound to its coenzyme, was increased by $0.13 \mathrm{nmol} / \mathrm{mg}$ of protein per min by the vitamin $\mathrm{B}_{12}$ supplement $(P=0.05$; Table 4$)$. Nevertheless, the percentage of holomutase activity from total methylmalonyl-CoA mutase specific activity was not different among treatments $(P \geq 0.16$; Table 4$)$ and was less than $5 \%$ as reported by Nakao et al. (2009) in rat liver.

Whole-Body Glucose and Propionate Kinetics. Plasma concentration of glucose during the tracer infusions was unaffected by treatments and averaged 3.51 $\pm 0.13 \mathrm{~m} M(P \geq 0.66$; Table 5$)$. Net portal appearance of propionate in early lactating cows reported by Reynolds et al. (2003) and Raun and Kristensen (2011) was in the same range as the WB propionate $\mathrm{Ra}$ in the current experiment. Whole-body glucose Ra in the current study was larger than previously reported in some studies infusing $\mathrm{D}-\left[6,6-{ }^{2} \mathrm{H}_{2}\right]$-glucose to dairy cows at later stages of lactation, but the ratio of milk lactose to WB glucose Ra was in a similar range (Lemosquet et al., 2009a; Galindo et al., 2011; Maxin et al., 2013).

The WB Ra of propionate was not affected by treatments $(P \geq 0.46$; Table 5$)$ in line with no effect of the supplements of vitamins on DMI. Propionate is the major glucogenic precursor in fed ruminants, although lactate and glucogenic AA can also contribute to a lesser extent to gluconeogenesis (Reynolds, 2006; Larsen and Kristensen, 2013). To enter into the Krebs cycle, propionate has to be successively transformed (Scott, 1999). One reaction involves methylmalonylCoA mutase and vitamin $\mathrm{B}_{12}$ as a coenzyme; a lack of vitamin $B_{12}$ impedes this reaction (Scott, 1999). In lactating ewes, gluconeogenesis from propionate was improved when using intramuscular injections of vitamin $B_{12}$ (Peters and Elliot, 1983). Accordingly, Preynat

Table 4. Effects of intramuscular injections of folic acid and vitamin $\mathrm{B}_{12}$ on hepatic concentrations of folates and vitamin $\mathrm{B}_{12}$, expression of selected genes, and methylmalonyl-CoA mutase activity at $64 \pm 3 \mathrm{DIM}^{1}$

\begin{tabular}{|c|c|c|c|c|c|c|c|c|}
\hline \multirow[b]{2}{*}{ Item } & \multicolumn{4}{|c|}{ Treatment $^{2}$} & \multirow[b]{2}{*}{ SEM } & \multicolumn{3}{|c|}{$P$-value } \\
\hline & $\mathrm{B}_{9}-\mathrm{B}_{12}-$ & $\mathrm{B}_{9}+\mathrm{B}_{12}-$ & $\mathrm{B}_{9}-\mathrm{B}_{12}+$ & $\mathrm{B}_{9}+\mathrm{B}_{12}+$ & & $\mathrm{B}_{9}$ & $\mathrm{~B}_{12}$ & $\mathrm{~B}_{9} \times \mathrm{B}_{12}$ \\
\hline Folate & 17.3 & 30.4 & 17.6 & 32.4 & 2.1 & $<0.0001$ & 0.57 & 0.68 \\
\hline Vitamin $B_{12}$ & 0.78 & 0.63 & 0.89 & 0.97 & 0.08 & 0.65 & 0.007 & 0.11 \\
\hline \multicolumn{9}{|l|}{ Gene expression ${ }^{3}$} \\
\hline$A H C Y$ & 1.64 & 1.22 & 1.41 & 2.03 & 0.16 & 0.51 & 0.07 & 0.004 \\
\hline$G N M T$ & 0.86 & 0.94 & 0.72 & 0.55 & 0.27 & 0.84 & 0.24 & 0.57 \\
\hline MTHFR & 0.98 & 0.73 & 1.06 & 0.94 & 0.15 & 0.23 & 0.32 & 0.67 \\
\hline$M U T$ & 1.18 & 0.80 & 1.10 & 1.37 & 0.20 & 0.77 & 0.21 & 0.09 \\
\hline \multicolumn{9}{|c|}{$\begin{array}{l}\text { Methylmalonyl-CoA mutase enzyme } \\
\text { activity, nmol/mg of protein per min }\end{array}$} \\
\hline Total & 13.84 & 14.11 & 14.97 & 14.65 & 0.71 & 0.97 & 0.25 & 0.68 \\
\hline Holomutase & 0.51 & 0.58 & 0.62 & 0.72 & 0.06 & 0.17 & 0.05 & 0.81 \\
\hline
\end{tabular}

${ }^{1}$ LSM with SEM, $n=6$ except for vitamin analyses, where $n=5$ because the amount of liver sample from 1 cow was not sufficient; the largest SEM is given.

${ }^{2} \mathrm{~B}_{9}-\mathrm{B}_{12}-=$ no vitamin supplement; $\mathrm{B}_{9}+\mathrm{B}_{12}-=320 \mathrm{mg}$ of folic acid; $\mathrm{B}_{9}-\mathrm{B}_{12}+=10 \mathrm{mg}$ of vitamin $\mathrm{B}_{12} ; \mathrm{B}_{9}+\mathrm{B}_{12}+=320 \mathrm{mg}$ of folic acid and $10 \mathrm{mg}$ of vitamin $\mathrm{B}_{12}$ given weekly from 3 wk before the expected calving date until 9 wk postpartum.

${ }^{3} A H C Y=$ S-adenosylhomocysteine hydrolase; $B H M T=$ betaine homocysteine methyltransferase; $C B S=$ cystathionine $\beta$-synthase; $G N M T=$ glycine $N$-methyltransferase; $M T H F R=5,10$-methylene-tetrahydrofolate reductase; $M U T=$ methylmalonyl-CoA mutase. 
Table 5. Effects of intramuscular injections of folic acid and vitamin $\mathrm{B}_{12}$ on whole-body (WB) glucose and propionate kinetics at $63 \pm 3$ DIM ${ }^{1}$

\begin{tabular}{|c|c|c|c|c|c|c|c|c|}
\hline Item & \multicolumn{4}{|c|}{ Treatment $^{2}$} & SEM & \multicolumn{3}{|c|}{$P$-value } \\
\hline Cows, $n$ & 6 & 5 & 6 & 6 & & & & \\
\hline \multicolumn{9}{|l|}{ Glucose } \\
\hline Plasma glucose, $\mathrm{m} M$ & 3.52 & 3.48 & 3.48 & 3.55 & 0.11 & 0.92 & 0.93 & 0.66 \\
\hline WB glucose $\mathrm{Ra},{ }^{3} \mathrm{mmol} / \mathrm{h}$ & 848 & 772 & 810 & 780 & 32 & 0.10 & 0.64 & 0.45 \\
\hline Milk lactose/WB glucose $\mathrm{Ra},{ }^{4} \%$ & 50.8 & 44.7 & 53.7 & 49.6 & 3.1 & 0.09 & 0.19 & 0.73 \\
\hline Glucose Ra from propionate, $\%$ & 64.6 & 61.3 & 58.3 & 54.7 & 8.5 & 0.65 & 0.39 & 0.98 \\
\hline Glucose Ra from propionate, $\mathrm{mmol} / \mathrm{h}$ & 545 & 467 & 473 & 437 & 78 & 0.42 & 0.45 & 0.75 \\
\hline
\end{tabular}

${ }^{1} \mathrm{LSM}$ with SEM, $\mathrm{n}$ is as given except for propionate results, treatment $\mathrm{B}_{9}+\mathrm{B}_{12}+$, where $\mathrm{n}=4$ because 2 cows were discarded due to a problem with ruminal catheter. The largest SEM is given.

${ }^{2} \mathrm{~B}_{9}-\mathrm{B}_{12}-=$ no vitamin supplement; $\mathrm{B}_{9}+\mathrm{B}_{12}-=320 \mathrm{mg}$ of folic acid; $\mathrm{B}_{9}-\mathrm{B}_{12}+=10 \mathrm{mg}$ of vitamin $\mathrm{B}_{12} ; \mathrm{B}_{9}+\mathrm{B}_{12}+=320 \mathrm{mg}$ of folic acid and $10 \mathrm{mg}$ of vitamin $\mathrm{B}_{12}$ given weekly from $3 \mathrm{wk}$ before the expected calving date until 9 wk postpartum.

${ }^{3}$ Whole-body glucose and propionate rate of appearance (Ra) measured using D- $\left[6,6-{ }^{2} \mathrm{H}_{2}\right]$-glucose and $\left[1-{ }^{13} \mathrm{C}\right]$-sodium propionate continuous and simultaneous infusions.

${ }^{4}$ Ratio calculated from lactose expressed in glucose equivalent and WB Ra of glucose.

et al. (2009a) observed that a combined supplement of folic acid and vitamin $\mathrm{B}_{12}$ increased WB glucose Ra at wk 12 of lactation and hypothesized that this effect could be due to an enhancement of propionate usage for gluconeogenesis. However, in the current study, in spite of the effects of the vitamin supplements on the hepatic abundance of MUT and holomutase activity, the glucose WB $\mathrm{Ra}$ and the glucose $\mathrm{Ra}$ from propionate, either as absolute flux or proportion, were not affected by vitamin $\mathrm{B}_{12}$ supplementation $(P \geq 0.39$; Table 5$)$. The proportion of glucose Ra from propionate averaged $59.7 \pm 8.5 \%$ and is in accordance with the contribution of propionate to glucose synthesis levels reported in the literature (50 to $58 \%$ ) for cows in early lactation (Amaral et al., 1990; Danfær et al., 1995; Larsen and Kristensen, 2013).

Whole-body glucose Ra represents the sum of glucose synthesis via gluconeogenesis, glucose absorption from the hepatic portal-drained viscera, and glycogenolysis (Lemosquet et al., 2009b; Galindo et al., 2011). Whole-body glucose Ra for cows receiving the folic acid supplement tended to be lower by $229 \mathrm{~g} / \mathrm{d}(P=0.10)$ compared with cows that did not, which is in line with the lower lactose synthesis $(-250 \mathrm{~g} / \mathrm{d})$ observed in these cows. In contrary, WB glucose Ra in the study of Preynat et al. (2009a) tended to increase by $160 \mathrm{~g} / \mathrm{d}$ with the combined supplement of folic acid and vitamin $\mathrm{B}_{12}$ at wk 12 of lactation and was associated with a similar increase in milk lactose secretion $(+165 \mathrm{~g} / \mathrm{d})$. In the current study, DMI was not different among treatment groups; it is then unlikely that the decrease of WB glucose Ra observed with supplementary folic acid was due to change in portal glucose absorption, and neither was the WB Ra of propionate affected by treatments.
In the current study, the proportion of WB glucose Ra to milk lactose tended to decrease with the folic acid supplement by $5.0 \%$ ( $P=0.09$; Table 5$)$. Mammary gland is the primary user of glucose, mammary glucose uptake varying between 69 to $85 \%$ of WB glucose Ra, whereas milk lactose yield to mammary glucose uptake ratio varied from 57 to $79 \%$ (Lemosquet et al., 2009b; Galindo et al., 2011). In the current experiment, either glucose utilization in tissues other than mammary gland or glucose utilization in the mammary gland for other purposes than lactose synthesis could have been favored with the use of the folic acid supplement. The former would agree better with results observed in those cows during the first $7 \mathrm{wk}$ of lactation when the folic acid supplement had no effect on DMI and milk TS yields, but reduced BCS losses, decreased plasma concentration of NEFA, and increased plasma concentrations of glucose and insulin (Duplessis et al., 2017). Results from Graulet et al. (2007), Preynat et al. (2009b), and Duplessis et al. (2014) also indicated that the vitamin supplements altered the energy partitioning.

The major difference between our study and those of Graulet et al. (2007) and Preynat et al. (2009b) seems to be the vitamin status of the studied animals. Concentrations of folates and vitamin $\mathrm{B}_{12}$ in plasma, milk, and liver, and plasma concentrations of Cys, Hcy, and Met (related to the methylation pathway) of the control cows $\left(\mathrm{B}_{9}-\mathrm{B}_{12}-\right.$ cows $)$ at wk 9 of lactation were compared with concentrations at wk 8 postpartum from these 2 previous studies (Graulet et al., 2007; Preynat et al., 2009b, 2010). Plasma, milk and liver concentrations of folates of control cows were higher on average by 18,33 , and $119 \%$, respectively, in the present experiment than in the 2 other experiments as 
well as plasma concentration of vitamin $B_{12}$ by 72 and $78 \%$. These comparisons indicate that, even without vitamin supplementation, control cows in the current study already had less potential to be deficient in folate and vitamin $\mathrm{B}_{12}$ at wk 9 than in the 2 compared studies. In opposition to liver folate concentration, hepatic vitamin $\mathrm{B}_{12}$ concentration of control cows was lower on average by $13 \%$ in the current trial compared with the 2 other studies. As folates and vitamin $\mathrm{B}_{12}$ are stored in the liver (Le Grusse and Watier, 1993), it shows that, in opposition to folates, less vitamin $\mathrm{B}_{12}$ was stored in the liver of the control cows in the present trial than in the 2 other studies although the plasma concentration of vitamin $\mathrm{B}_{12}$ was higher.

Regarding AA related to the methylation pathway, plasma concentrations of Cys and Met in control cows were higher on average by 16 and $28 \%$, respectively, and plasma concentration of Hcy was lower on average by $14 \%$ in this experiment than in the 2 other studies. In the Met cycle, Hcy could either be remethylated to Met or be irreversibly catabolized to Cys through the transsulfuration pathway (Bertolo and McBreairty, 2013). When Met is in excess, conversion of Met to Hcy (transmethylation) and transsulfuration are upregulated as Met is toxic at relatively low concentrations (Bertolo and McBreairty, 2013). As plasma Met and Cys concentrations were higher in control cows than in the 2 other trials, it could be hypothesized that the transsulfuration pathway was already upregulated to eliminate extra Met.

\section{CONCLUSIONS}

Plasma concentrations of folic acid, vitamin $\mathrm{B}_{12}$, Met, and Cys of control cows in the present experiment were higher than previously reported and suggest that the supply of folic acid and vitamin $\mathrm{B}_{12}$ from ruminal synthesis was sufficient to optimize transmethylation pathway and performance of dairy cows under conditions of the current study. Moreover, the absence of treatment effect on plasma concentrations of methylmalonic acid as well as on the proportion of glucose synthesized from propionate, averaging $60 \%$, also supports the fact that vitamin $\mathrm{B}_{12}$ supply was sufficient. However, milk and lactose yields tended to decrease with the folic acid supplement as did the WB glucose Ra. Consequently, as previously observed in other studies, supplementary folic acid and vitamin $\mathrm{B}_{12}$ may alter energy partitioning in cows but, in the present experiment, it seems to have been at the expense of milk lactose secretion. These results highlight the necessity to develop a tool to predict supplies of folic acid and vitamin $\mathrm{B}_{12}$ from ruminal synthesis according to diet management, to predict when supplementation with these vitamins would be appropriate.

\section{ACKNOWLEDGMENTS}

The authors are grateful to Véronique Roy, Valérie Beaudet, Jocelyne Renaud, Chrystiane Plante, Mario Léonard, Catherine Thibault, Isabelle Blanchet, and Liette Veilleux (Agriculture et Agroalimentaire Canada, Sherbrooke, Québec, Canada) for technical assistance, and Steve Méthot (Agriculture et Agroalimentaire Canada, Sherbrooke, Québec, Canada) for his statistical advice. We acknowledge the invaluable help of Marie-Ève Bouchard, Étienne Viens, and the barn staff (Agriculture et Agroalimentaire Canada, Sherbrooke, Québec, Canada) for special care of dairy cows throughout the experiment and Mario Gauthier (Valacta, Sainte-Annede-Bellevue, Québec, Canada) for diet formulation. We appreciate the help of Antoine Bourgeois (Clinique Vétérinaire de Sherbrooke, Québec, Canada) and Éric Martineau (Clinique Vétérinaire de Coaticook, Québec, Canada) who performed surgeries and liver biopsies, respectively. We also thank Vétoquinol (Lavaltrie, Québec, Canada) for generously providing vitamin $\mathrm{B}_{12}$. This project was funded by the Programme de recherche en partenariat pour l'innovation en production et transformation laitière Novalait-Agriculture et Agroalimentaire Canada-Fonds de recherche du Québec Nature et Technologies-Ministère de l'Agriculture, des Pêcheries et de l'Alimentation du Québec, Québec, Canada.

\section{REFERENCES}

Akins, M. S., S. J. Bertics, M. T. Socha, and R. D. Shaver. 2013 Effects of cobalt supplementation and vitamin $\mathrm{B}_{12}$ injections on lactation performance and metabolism of Holstein dairy cows. J. Dairy Sci. 96:1755-1768.

Amaral, D. M., J. J. Veenhuizen, J. K. Drackley, M. H. Cooley, A. D. McGilliard, and J. W. Young. 1990. Metabolism of propionate, glucose, and carbon dioxide as affected by exogenous glucose in dairy cows at energy equilibrium. J. Dairy Sci. 73:1244-1254.

Andersen, C. L., J. L. Jensen, and T. F. Orntoft. 2004. Normalization of real-time quantitative reverse transcription-PCR data: A model-based variance estimation approach to identify genes suited for normalization, applied to bladder and colon cancer data sets. Cancer Res. 64:5245-5250.

Bertolo, R. F., and L. E. McBreairty. 2013. The nutritional burden of methylation reactions. Curr. Opin. Clin. Nutr. Metab. Care 16:102-108.

Canadian Council on Animal Care. 2009. Guide to the care and use of experimental animals. 2nd ed. Vol. 1. E. D. Rolfert, B. M. Cross, and A. A. McWilliam, ed. Can. Counc. Anim. Care, Ottawa, Ontario, Canada.

Danfær, A., V. Tetens, and N. Agergaard. 1995. Review and an experimental study on the physiological and quantitative aspects of gluconeogenesis in lactating ruminants. Comp. Biochem. Physiol. B Biochem. Mol. Biol. 111:201-210.

Dudemaine, P. L., G. Fecteau, M. Lessard, O. Labrecque, J. P. Roy, and N. Bissonnette. 2014. Increased blood-circulating interferon- $\gamma$, 
interleukin-17, and osteopontin levels in bovine paratuberculosis. J. Dairy Sci. 97:3382-3393.

Duplessis, M., C. L. Girard, D. E. Santschi, D. M. Lefebvre, and D. Pellerin. 2014. Milk production and composition, and body measurements of dairy cows receiving intramuscular injections of folic acid and vitamin $\mathrm{B}_{12}$ in commercial dairy herds. Livest. Sci. 167:186-194.

Duplessis, M., H. Lapierre, D. Pellerin, J. P. Laforest, and C. L. Girard. 2017. Effects of intramuscular injections of folic acid, vitamin $\mathrm{B}_{12}$, or both, on lactational performance and energy status of multiparous dairy cows. J. Dairy Sci. 100:4051-4064.

Duplessis, M., S. Mann, D. V. Nydam, C. L. Girard, D. Pellerin, and T. R. Overton. 2015. Short communication: Folates and vitamin $\mathrm{B}_{12}$ in colostrum and milk from dairy cows fed different energy levels during the dry period. J. Dairy Sci. 98:5454-5459.

Ferguson, J. D., D. T. Galligan, and N. Thomsen. 1994. Principal descriptors of body condition score in Holstein cows. J. Dairy Sci. 77:2695-2703.

Finkelstein, J. D. 1990. Methionine metabolism in mammals. J. Nutr. Biochem. 1:228-237.

Galindo, C. E., D. R. Ouellet, D. Pellerin, S. Lemosquet, I. OrtiguesMarty, and H. Lapierre. 2011. Effect of amino acid or casein supply on whole-body, splanchnic, and mammary glucose kinetics in lactating dairy cows. J. Dairy Sci. 94:5558-5568.

Girard, C. L., and J. J. Matte. 2005. Effects of intramuscular injections of vitamin $B_{12}$ on lactation performance of dairy cows fed dietary supplements of folic acid and rumen-protected methionine. J. Dairy Sci. 88:671-676.

Goff, J. P., and R. L. Horst. 1997. Physiological changes at parturition and their relationship to metabolic disorders. J. Dairy Sci. 80:1260-1268.

Graulet, B., J. J. Matte, A. Desrochers, L. Doepel, M.-F. Palin, and C. L. Girard. 2007. Effects of dietary supplements of folic acid and vitamin $\mathrm{B}_{12}$ on metabolism of dairy cows in early lactation. J. Dairy Sci. 90:3442-3455.

Larsen, M., and N. B. Kristensen. 2013. Precursors for liver gluconeogenesis in periparturient dairy cows. Animal 7:1640-1650.

Le Grusse, J., and B. Watier. 1993. Les vitamines. Données biochimiques, nutritionnelles et cliniques. Centre d'étude et d'information sur les vitamines, Produits Roche, Neuilly-sur-Seine, France.

Lemosquet, S., E. Delamaire, H. Lapierre, J. W. Blum, and J. L. Peyraud. 2009a. Effects of glucose, propionic acid, and nonessential amino acids on glucose metabolism and milk yield in Holstein dairy cows. J. Dairy Sci. 92:3244-3257.

Lemosquet, S., G. Raggio, G. E. Lobley, H. Rulquin, J. Guinard-Flament, and H. Lapierre. 2009b. Whole-body glucose metabolism and mammary energetic nutrient metabolism in lactating dairy cows receiving digestive infusions of casein and propionic acid. J. Dairy Sci. 92:6068-6082.

Lévesque-Sergerie, J. P., M. Duquette, C. Thibault, L. Delbecchi, and N. Bissonnette. 2007. Detection limits of several commercial reverse transcriptase enzymes: Impact on the low- and high-abundance transcript levels assessed by quantitative RT-PCR. BMC Mol. Biol. 8:93-110.

Maxin, G., D. R. Ouellet, and H. Lapierre. 2013. Effect of substitution of soybean meal by canola meal or distillers grains in dairy rations on amino acid and glucose availability. J. Dairy Sci. 96:7806-7817.

Mayes, P. A. 1981. Metabolism of carbohydrate. Pages 160-185 in Harper's Review of Biochemistry. 18th ed. D. W. Martin, P. A.
Mayes, and V. W. Rodwell, ed. Lange Medical Publications, Los Aktos, CA.

McArt, J. A. A., D. V. Nydam, G. R. Oetzel, T. R. Overton, and P. A. Ospina. 2013. Elevated non-esterified fatty acids and $\beta$-hydroxybutyrate and their association with transition dairy cow performance. Vet. J. 198:560-570.

Nakao, M., S. Hironaka, N. Harada, T. Adachi, T. Bito, Y. Yabuta, F. Watanabe, T. Miura, R. Yamaji, H. Inui, and Y. Nakano. 2009 Cobalamin deficiency results in an abnormal increase in L-methylmalonyl-co-enzyme-A mutase expression in rat liver and COS-7 cells. Br. J. Nutr. 101:492-498.

National Farm Animal Care Council. 2009. Code of practice for the care and handling of dairy cattle. Dairy Farmers of Canada and National Farm Animals Care Council, Ottawa, Ontario, Canada.

Ouattara, B., N. Bissonnette, M. Duplessis, and C. L. Girard. 2016. Supplements of vitamins $\mathrm{B}_{9}$ and $\mathrm{B}_{12}$ affect hepatic and mammary gland gene expression profiles in lactating dairy cows. BMC Genomics 17:640.

Ouattara, B., M. Duplessis, and C. L. Girard. 2013. Optimization and validation of a reversed-phase high performance liquid chromatography method for the measurement of bovine liver methylmalonylcoenzyme a mutase activity. BMC Biochem. 14:25-35.

Peters, J. P., and J. M. Elliot. 1983. Effect of vitamin $B_{12}$ status on performance of the lactating ewe and gluconeogenesis from propionate. J. Dairy Sci. 66:1917-1925.

Preynat, A., H. Lapierre, M. C. Thivierge, M. F. Palin, N. Cardinault, J. J. Matte, A. Desrochers, and C. L. Girard. 2010. Effects of supplementary folic acid and vitamin $\mathrm{B}_{12}$ on hepatic metabolism of dairy cows according to methionine supply. J. Dairy Sci. 93:21302142.

Preynat, A., H. Lapierre, M. C. Thivierge, M. F. Palin, J. J. Matte, A. Desrochers, and C. L. Girard. 2009a. Effects of supplements of folic acid, vitamin $\mathrm{B}_{12}$, and rumen-protected methionine on whole body metabolism of methionine and glucose in lactating dairy cows. J. Dairy Sci. 92:677-689.

Preynat, A., H. Lapierre, M. C. Thivierge, M. F. Palin, J. J. Matte, A. Desrochers, and C. L. Girard. 2009b. Influence of methionine supply on the response of lactational performance of dairy cows to supplementary folic acid and vitamin $B_{12}$. J. Dairy Sci. 92:16851695.

Raun, B. M. L., and N. B. Kristensen. 2011. Metabolic effects of feeding ethanol or propanol to postpartum transition Holstein cows. J. Dairy Sci. 94:2566-2580.

Reynolds, C. K. 2006. Production and metabolic effects of site of starch digestion in dairy cattle. Anim. Feed Sci. Technol. 130:78-94.

Reynolds, C. K., P. C. Aikman, B. Lupoli, D. J. Humphries, and D. E. Beever. 2003. Splanchnic metabolism of dairy cows during the transition from late gestation through early lactation. J. Dairy Sci. 86:1201-1217.

Santschi, D. E., R. Berthiaume, J. J. Matte, A. F. Mustafa, and C. L. Girard. 2005. Fate of supplementary B-vitamins in the gastrointestinal tract of dairy cows. J. Dairy Sci. 88:2043-2054.

SAS Institute Inc. 2012. User's Guide: Statistics. Version 9.4. SAS Institute Inc., Cary, NC.

Scott, J. M. 1999. Folate and vitamin $B_{12}$. Proc. Nutr. Soc. 58:441-448.

Wildman, E. E., G. M. Jones, P. E. Wagner, R. L. Boman, H. F. Troutt Jr., and T. N. Lesch. 1982. A dairy cow body condition scoring system and its relationship to selected production characteristics. J. Dairy Sci. 65:495-501. 